\title{
The recording of floods and earthquakes in Lake Chichój, Guatemala during the twentieth century
}

\author{
Gilles Brocard • Thierry Adatte • Olivier Magand • \\ Hans-Rudolf Pfeifer • Albedo Bettini • Fabien Arnaud • \\ Flavio S. Anselmetti · Sergio Moran-Ical
}

Received: 29 November 2012/Accepted: 8 July 2014/Published online: 22 July 2014

(C) Springer Science+Business Media Dordrecht 2014

\begin{abstract}
Laguna Chichój (Lake Chichój) is the only deep permanent lake in the central highlands of Guatemala. The lake is located in the boundary zone between the North American and Caribbean plates. The lake has been struck by devastating earthquakes and tropical cyclones in historical times. We investigated the imprint of twentieth century extreme events on the sedimentary record of this tropical lake using a bathymetric survey of the lake, coring the lake floor, and providing a chronology of sediment accumulation. The lake occupies a series of circular depressions likely formed by the rapid dissolution of a buried body of gypsum. ${ }^{210} \mathrm{~Pb}$ and ${ }^{137} \mathrm{Cs}$ inventories and varve counting indicate high rates of sedimentation
\end{abstract}

Electronic supplementary material The online version of this article (doi:10.1007/s10933-014-9784-4) contains supplementary material, which is available to authorized users.

G. Brocard $(\bowtie) \cdot$ T. Adatte $\cdot$ H.-R. Pfeifer $~ A . ~ B e t t i n i$ Faculté des Géosciences et de l'Environnement, Université de Lausanne, Lausanne, Switzerland e-mail: gbrocard@sas.upenn.edu

Present Address:

G. Brocard

Department of Earth and Environmental Science,

University of Pennsylvania, Philadelphia, PA, USA

\section{O. Magand}

Laboratoire de Glaciologie et Géophysique de l'Environnement (LGGE), Université de Grenoble, Grenoble, France $\left(1-2 \mathrm{~cm}_{\text {year }}{ }^{-1}\right)$. The annually layered sediment is interrupted by turbidites of two types: a darker-colored turbidite, enriched in lake-derived biogenic constituents, and interpreted as a seismite, and a lightercolored type, enriched in catchment-derived constituents, interpreted as a flood layer. Comparison of our ${ }^{137} \mathrm{Cs}$-determined layer ages with a catalog of twentieth century earthquakes shows that an earthquake on the Motagua fault in 1976 generated a conspicuous darker-colored turbidite and slumped deposits in separate parts of the lake. The entire earthquake inventory further reveals that mass movements in the lake are triggered at Modified Mercalli Intensities higher than V. Tropical cyclonic depressions known to have affected the lake area had limited effect on the lake, including Hurricane Mitch in 1998. One storm however produced a significantly thicker flood layer in the 1940s. This storm is reportedly the only event to

\author{
F. Arnaud \\ Environnement, DYnamiques et TErritoire de la \\ Montagne (EDYTEM), Université de Savoie, Annecy, \\ France \\ F. S. Anselmetti \\ Institute of Geological Sciences, University of Bern, Bern, \\ Switzerland \\ S. Moran-Ical \\ CUNOR, Universidad de San Carlos Guatemala, \\ Guatemala City, Guatemala
}


have generated widespread slope failures in the lake catchment. It is thus inferred that abundant landsliding provided large amounts of concentrated sediment to the lake, through hyperpycnal flows.

Keywords Guatemala $\cdot$ Lake $\cdot$ Seismites · Hurricane $\cdot$ Twentieth century $\cdot$ Earthquake

\section{Introduction}

Guatemala is a country frequently struck by devastating earthquakes due to its location over the triple junction between the North American, Caribbean and Cocos plates. The country also lies in the path of many tropical depressions and hurricanes. Lake sediments are commonly used to assess earthquake recurrence (Arnaud et al. 2002; Schnellmann et al. 2002; Monecke et al. 2004; Lauterbach et al. 2012), flood recurrence (Arnaud et al. 2002; Wirth et al. 2011; Wilhelm et al. 2012; Swierczynski et al. 2012), and hurricane frequency in the tropics (Malaizé et al. 2011). Thus far, limnological studies in Guatemala have targeted the Petén lowlands of northern Guatemala (Binford et al. 1987; Anselmetti et al. 2007) and the volcanic highlands of western Guatemala (Brezonik and Fox 1974; Poppe et al. 1985; Newhall et al. 1987). Located on a karstified plateau at an elevation of 1,400 m, Lake Chichój is the only deep (>2 m) natural permanent lake of the central highlands (Fig. 1). Caribbean and Pacific hurricanes have struck its catchment several times during the twentieth century (Fig. 2a). The lake is also located within $2 \mathrm{~km}$ of the Polochic fault and $45 \mathrm{~km}$ from the Motagua fault, two very large faults that currently define the plate boundary between the Caribbean and North American Plates (Figs. 2b, 3; Lyon-Caen et al. 2006; Authemayou et al. 2012). Both faults have ruptured several times since $1520 \mathrm{AD}$, generating earthquakes reaching magnitude 7 and higher (Fig. 2b; Plafker 1976; White 1984). We investigated the imprint of twentieth century extreme events on the lakes sedimentary record using a bathymetric survey of the lake, coring of the lake floor and providing a chronology of sediment accumulation. Facies analysis, XRF mineralogical characterization and grainsize analysis were used to discriminate source areas and triggering processes. $\mathrm{A}^{210 \mathrm{~Pb}}$ and ${ }^{137} \mathrm{Cs}$-based age model was used to estimate the age of the main events, which were then compared to seismological and meteorological records in order to assess the sensitivity of the lake to hurricanes and earthquakes.

Study site

Lake Chichój is composed of three basins separated by very shallow sills (Fig. 1), the West basin being the largest $(550 \times 450 \mathrm{~m})$ and deepest $(32 \mathrm{~m})$. Further east, a 5- to 10-m-deep area surrounds the delta of the Chijuljá River, the main and only perennial tributary of the lake. A 2-m-deep sill separates this central area from a second, 25-m-deep circular basin, $250 \mathrm{~m}$ in diameter, referred to as the Peténcito Basin for its location near the Peténcito Hill. The lake terminates to the east in a small, 16-m-deep circular depression (Eastern Hole) only $60 \mathrm{~m}$ in diameter. The Eastern Hole is separated from the Peténcito Basin by another 2-m-deep sill. Contrasting with the steep inner topography of the lake, flat wetlands surround the lake on almost all sides. The outflow channel initiates over the sill that separates the Peténcito Basin from the Eastern Hole. The outflow channel is straight, $2 \mathrm{~m}$ deep, and flows northwards for $350 \mathrm{~m}$ across wetlands before reaching the surrounding hills. Wetlands surround the lake on almost all sides and stretch over an area 1.3 times larger than the lake itself. They are flooded each year during high stands. The lake itself an area of $0.5 \mathrm{~km}^{2}$ and has a volume of $4.8 \pm 0.1 \times 10^{6} \mathrm{~m}^{3}$. Its level fluctuates by a few tens of centimeters from the rainy season (May-October, $300 \mathrm{~mm} \mathrm{month}^{-1}$ ) to the dry season (November-April, $100 \mathrm{~mm} \mathrm{month}^{-1}$ ). During intense rainy seasons (500-600 $\mathrm{mm} \mathrm{month}^{-1}$ ), the lake surface reaches a $+1.1 \mathrm{~m}$ high stand, and then expands over an area delimited by a shoreline well visible on aerial photographs (Fig. 1). The lake volume then peaks at $5.1 \pm 0.1 \times 10^{6} \mathrm{~m}^{3}$.

The environmental and geologic history of Lake Chichój is only documented in a handful of historical notes and in a few recent technical reports. Lake Chichój is only $1.75 \mathrm{~km}$ long, bordered to the north by the city of San Cristóbal Verapaz, an urban center of $\sim 12,500$ inhabitants (Fig. 1). The town was a Mayan Poqomchí settlement at the time of the Spanish conquest at around $1545 \mathrm{AD}$ (Terga 1979). The ground below or near the lake may have experienced catastrophic collapse a few years after the Spanish 
Fig. 1 Bathymetric map of Lake Chichój with sediment cores location. Shaded lake bathymetry with depth contours every $5 \mathrm{~m}$ (blue lines), superposed onto a 2008 aerial photograph. Yellow lines bathymetric survey transects. Pink cross downfaulted sediments along lake shore. Inset location of Laguna Chichój in Guatemala, with indication of major lakes and tectonic faults: $P F$ Polochic fault, $M F$ Motagua fault. Red triangles are major active volcanic centers: SM Santa MariaSantiaguito, A Atitlán, $F$ Fuego, $P$ Pacaya. (Color figure online)

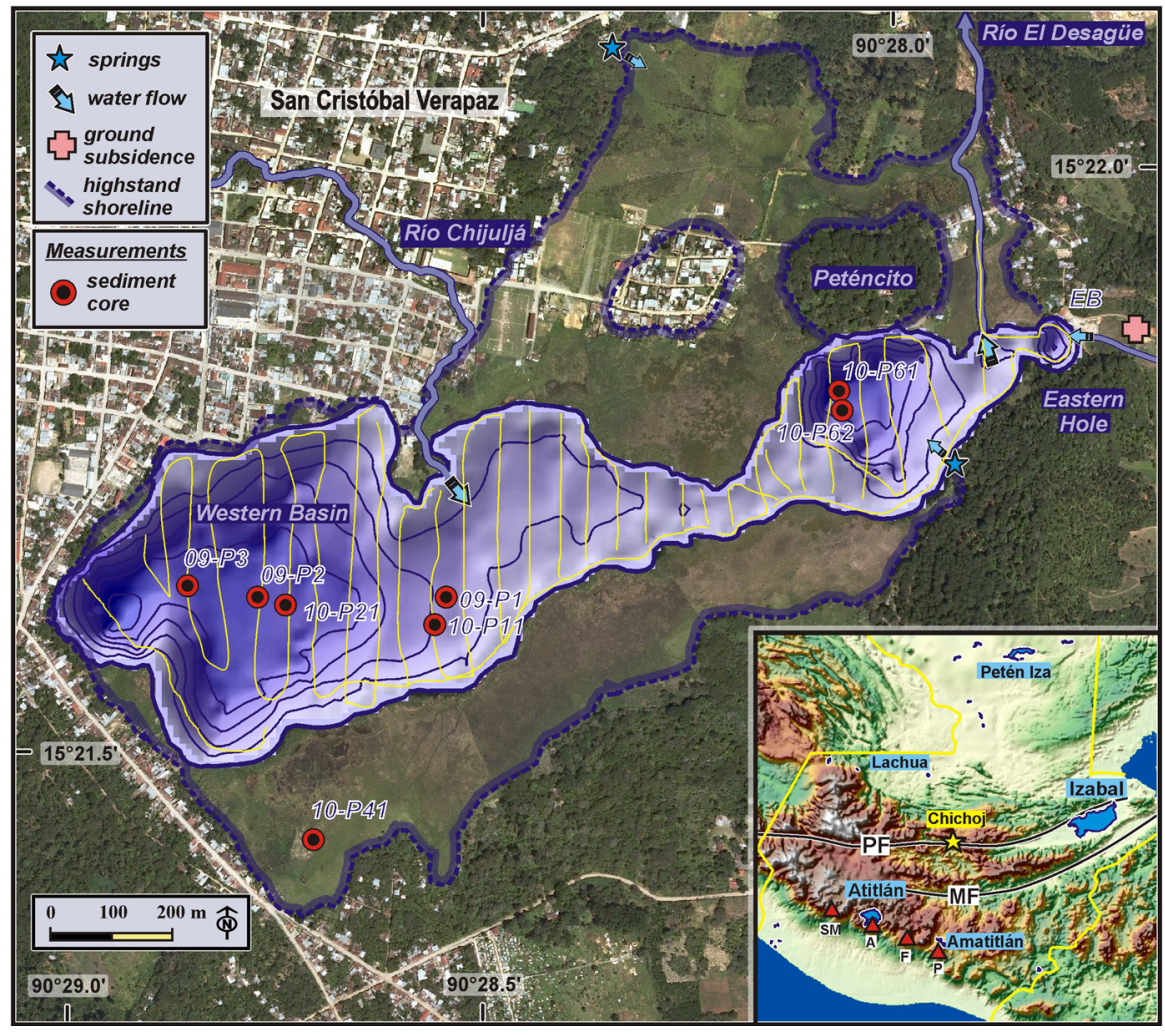

conquest. The collapse would have destroyed and drowned the antique settlement of San CristóbalKaj-Koj (Gage 1648), feeding legends to this day. Gage's report suffers many exaggerations, casting doubt on the validity of this testimony. An independent Spanish archive mentions that a sudden 'collapse' affected the lake area following an earthquake in 1590 AD (Viana et al. 1955), but spared the local church (White 1984). In recent time deforestation, changes in agricultural practices, demographic growth, urbanization, industrialization, and destruction of wetlands promoted soil erosion, lake contamination and eutrophication (Alpizurez-Palma 1978; Arce-Canahui 1992; Mouriño et al. 1994; Alvarez-Rangel 1995; Mijangos 2000; Bettini 2011).

The catchment of the lake is underlain by Cretaceous and Permian carbonates, as well as Jurassic fluvial deposits (Fig. 3), all almost completely covered by thick, clay-rich tropical soils. A $84 \pm 5 \mathrm{ky}-$ old, regionally extensive rhyolitic pumice (Los Chocoyos Formation, Drexler et al. 1980; Rose et al. 1986) is encountered in low topographic positions where it forms deposits 10-20 m thick (Fig. 4). These deposits are frequently mobilized during earthquakes and hurricanes (Bucknam et al. 2001; Harp et al. 1981), during which occasions they can represent a substantial fraction of the sediment delivered to the streams.

The most seismogenic region of Guatemala is the Cocos subduction zone, in western Guatemala. It generated several earthquakes of $\mathrm{M}_{\mathrm{s}}>7$ during the twentieth century. These subduction-zone earthquakes reach Modified Mercalli Intensities (MMIs) of VIII along the volcanic arc (White et al. 2004), but nevertheless have caused fewer casualties than the less powerful, but much shallower upper-crustal earthquakes occurring within the volcanic arc (White and Harlow 1993; Fig. 2b). These earthquakes are attenuated to low MMIs before reaching Lake Chichój. Much closer to the lake, the boundary between the Caribbean and North American plates has produced the most destructive earthquake of the twentieth century in Guatemala on the 4th of February 1976. It had a magnitude of 7.5 and ruptured the Motagua fault over $210 \mathrm{~km}$, within $45 \mathrm{~km}$ of Lake Chichój. The earthquake was felt at the lake with a MMI of VI, and 

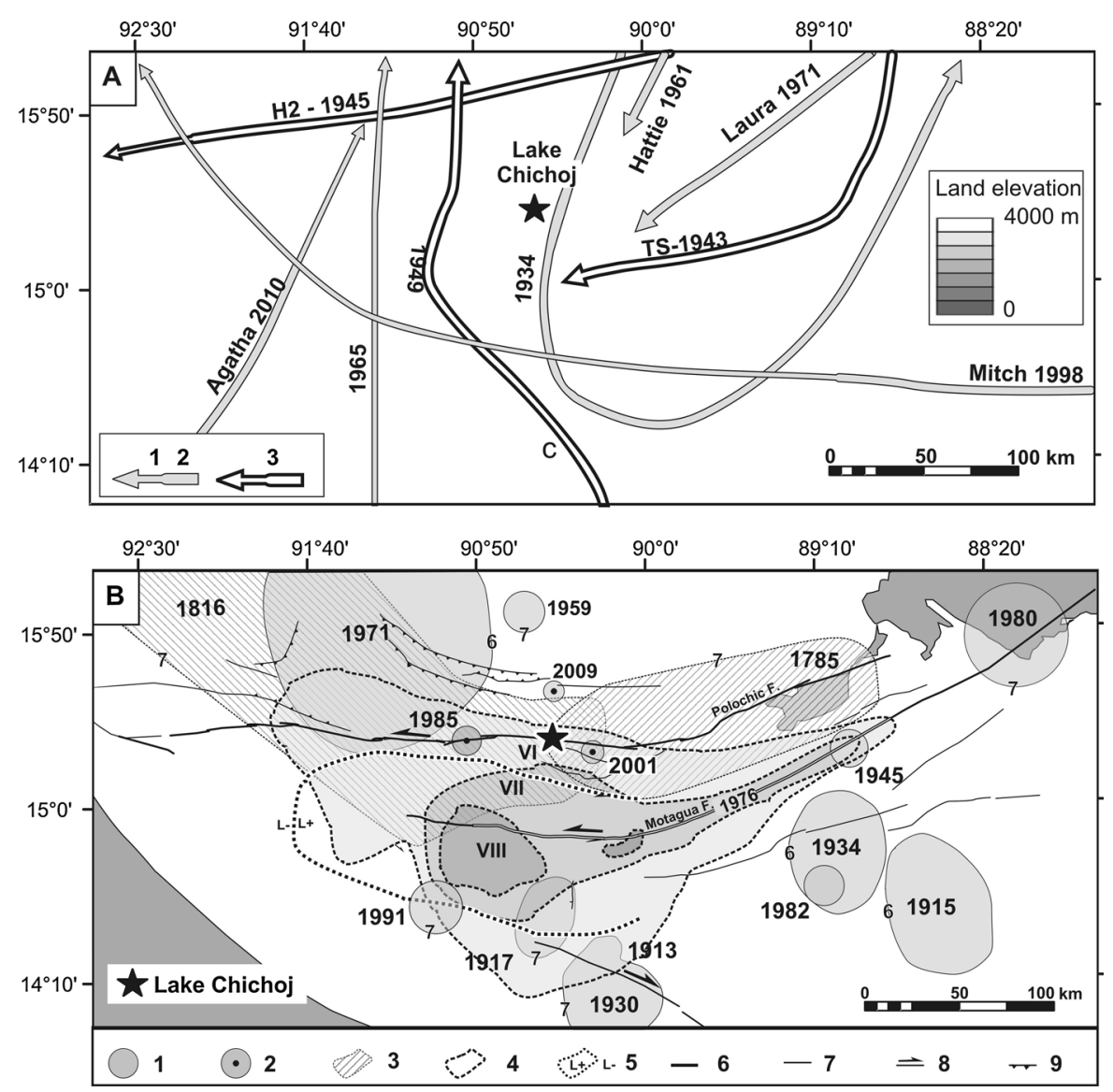

Fig. 2 Historical earthquakes and tropical storm tracks in central Guatemala. a Map showing reported tropical storms expected to have passed within $100 \mathrm{~km}$ of Lake Chichój during the twentieth century (NOAA database). 1 tracks of tropical depressions (1), 2 tropical storms, 3 storms the most likely responsible for layer 'c' in lake Chichój. b Isoseismal map of upper crustal destructive earthquakes. $1 \mathrm{M}>5.7$ upper crustal earthquakes, period 1900-1986, with delimiting MMIs in

damaged $70 \%$ of the adobe constructions of San Cristóbal (Espinoza et al. 1976; White 1984).

The Caribbean-North American plate boundary only produced very few other destructive earthquakes in the twentieth century, and destructions were observed only within a few kilometers from their epicenters (Fig. 2b). Some of these earthquakes occurred very close to Lake Chichój. The most noticeable one is the $\mathrm{M}_{\mathrm{w}}$ 5.0 Tierra Blanca earthquake, $40 \mathrm{~km}$ to the west of the lake, which damaged $90 \%$ of Uspantán in October 1985. Poorly built structures and site effects (Suski et al. 2010) explain the high local intensity of this event (MMI VII), and its area of
Arabic numbers (White and Harlow 1993), 2 M $>5.0$ earthquakes since 1985 within $50 \mathrm{~km}$ of the lake (INSIVUMEH database), $3 \mathrm{M}>7.0$ historical earthquakes of the Polochic fault (White 1984), 4 detailed areal distribution of the 1976 earthquake MMIs (Roman numbers), 5 Boundary of the 1976 earthquake-induced landslide area (Harp et al. 1981), 6 major fault, 7 minor fault, 8 strike-slip fault, 9 reverse fault

destruction limited to the city and its immediate surroundings. A shallow $\mathrm{M}_{\mathrm{w}} 5.3$ earthquake occurred in $200110 \mathrm{~km}$ to the $\mathrm{SE}$ of the lake but did not produced any noticeable damage at the surface. No earthquake other than the great 1976 Motagua earthquake was felt in San Cristóbal with intensity higher than $\mathrm{V}$ during the twentieth century. In earlier centuries, however, the lake area experienced much stronger shaking. The Polochic fault, which passes within $2 \mathrm{~km}$ of the lake, is another major fault of the plate boundary which is believed to have generated earthquakes reaching magnitudes larger than 7 in 1815 and 1785 AD (White 1984). 


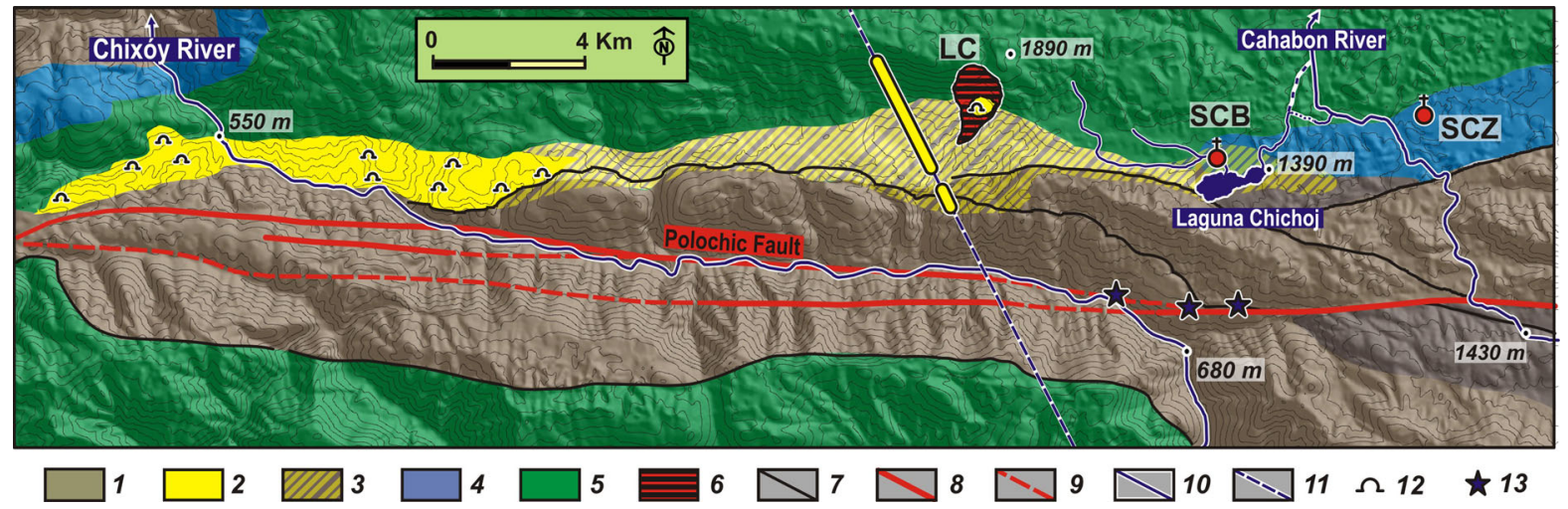

Fig. 3 Geologic sketch of the Polochic fault corridor near Lake Chichój. Modified from the Tactíc and Tiritibol geologic quadrangles, IGN, 1967 and 1966, over shaded topographic background contoured at 100-m intervals. Cities: SCB Santa Critóbal Verapaz, SCZ Santa Cruz Verapaz. LC Los Chorros 2009 rock avalanche collapse scar. Legend: 1 Permian shales and carbonates (Tactic and Chochál formations), 2 observable

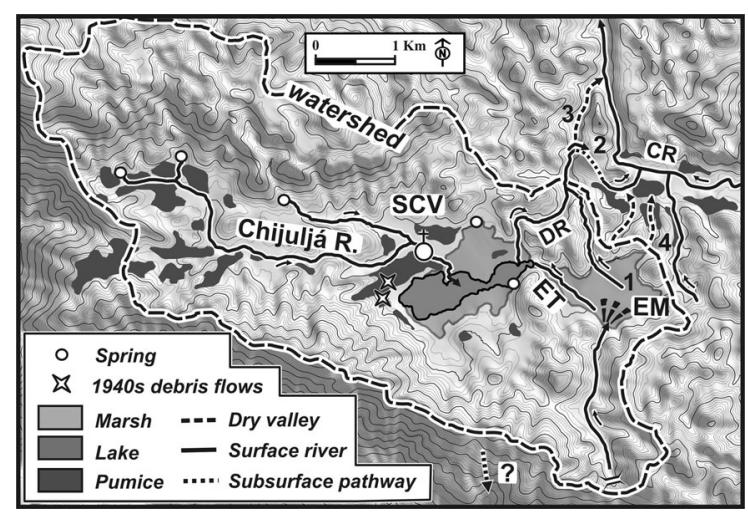

Fig. 4 Topography and hydrology of the lake catchment. Shaded relief map of the Lake Chichój catchment contoured every $10 \mathrm{~m}$ (thin lines) and $50 \mathrm{~m}$ (thick lines), showing its drainage, the distribution of known occurrences of Los Chocoyos pumice and 1940s debris flows. CR Cahabón River, $D R$ Desagüe River, EM Eastern Marsh, ET Eastern Tributary, $S C V$ city of San Cristóbal Verapaz

Less information is available regarding intense rainfall events that affected the lake in the twentieth century due to the scarcity of direct meteorological records within the lake catchment, as the first local meteorological stations were only set up in 1979. The most intense recorded event is Hurricane Mitch in 1998, one of the strongest and most devastating tropical storms to have impacted Central America over the past 250 years. Events capable of producing gypsum, 3 inferred underground extent of gypsum, 4 Jurassic continental red beds (Todos Santos Fm.), 5 Cretaceous Carbonates, 6 Los Chorros 2009 rock avalanche, 7 ancient tectonic contact, 8 active fault, observed, 9 active fault, inferred, 10 river, 11 subterraneous aqueduct (INDE 1974), 12 gypsum quarry, 13 large sulfate-bearing springs

extreme runoffs occur every 20 years in Guatemala (Lopez 1999), but the return period of events as large as Mitch ranges between 30 and 80 years (GuerraNoriega 2010). A 300-mm-rainfall event has an expected 100 year return period in southern Guatemala (Friedel 2008). Local storms, as well as synopticscale features such as easterly waves, fronts, and lowpressure systems can also produce intense rainfalls and generate exceptional runoff events. However, because hurricanes and tropical storms deliver $70 \%$ of the annual rainfall in the Caribbean region (Musk 1988) and are responsible for the most intense rainfall events in Guatemala (Lopez 1999; Guerra-Noriega 2010), we use the record of hurricane tracks (NOAA; Fig. 2a) as the best available proxy to identify extreme rainfall events in the lake area before 1979 AD.

\section{Methods}

\section{Bathymetric survey}

The lake was mapped in 2009 using a portable Hummingbird 570 DI echo sounder. Data acquisition was performed along meridian transects located 50-80 m apart (Fig. 1), with a $20 \mathrm{~m}$ average separation between sounding points, and an absolute GPS geographical positioning accuracy of 3-5 m. Navigation was hindered by the presence of large drifting 
rafts of floating macrophytes [Eichhornia crassipes, (Mart.) Solms], resulting in some unevenness in the coverage. The displayed bathymetric map (Fig. 1) is a natural neighbor interpolation over $\sim 1,400$ sounding points. The bathymetry is consistent with previous manual soundings (Alpizurez-Palma 1978), and with the depth measured during coring. An average vertical uncertainty of $\pm 1 \mathrm{~m}$ results from the choice of the interpolation method, and is propagated in lake volume calculations.

\section{Sediment coring}

Three 60- to 80-cm-long sediment cores were recovered from the proximal, central and distal part of the West Basin in June 2009, using a 63-mm-diameter UWITEC freefall gravity corer (Fig. 1). The cores were opened and photographed in the Laboratory for the Study of Environmental Archives of Mountainous Environment, at the University of Savoie, France. This initial coring was complemented in July 2010 by the sampling of additional cores in both the West Basin and the Peténcito Basin. These cores were split in halves and photographed at the Swiss Federal Institute of Aquatic Science and Technology (EAWAG).

\section{${ }^{210} \mathrm{~Pb}$ and ${ }^{137} \mathrm{Cs}$ sediment dating}

Core 09P2, from the central part of the West basin (Fig. 1), was used for a ${ }^{210} \mathrm{~Pb}$ and ${ }^{137} \mathrm{Cs}$ inventory. The core was sliced in centimeter intervals, dried at $105{ }^{\circ} \mathrm{C}$ for 24-48 $\mathrm{h}$ and weighed to estimate dry bulk density. We calculated cumulative mass depth, and homogenized the sediment before conditioning for gamma counting (Hernandez-Suarez and El-Daoushy 2002). Samples were introduced in polystyrene counting tubes $\left(11 \mathrm{~cm}^{3}\right),{ }^{210} \mathrm{~Pb}$ in lake sediments is a mixture of ${ }^{210} \mathrm{~Pb}$ formed within the sediment from the decay of ${ }^{226} \mathrm{Ra}$ deposited by soil erosion (supported ${ }^{210} \mathrm{~Pb}$ ), and of ${ }^{210} \mathrm{~Pb}$ formed in the atmosphere by the decay of ${ }^{222} \mathrm{Rn}$ (unsupported or excess ${ }^{210} \mathrm{~Pb}$ ). The decay of the atmospherically derived (excess) ${ }^{210} \mathrm{~Pb}$ provides a measure of the rate of sedimentation. Excess ${ }^{210} \mathrm{~Pb}$ is determined by subtracting the activity of ${ }^{226} \mathrm{Ra}$ from the total ${ }^{210} \mathrm{~Pb}$ activity (Noller 2000). Samples were measured for $24 \mathrm{~h}$ in a very-low background P-type germanium well detector (Canberra Industries) at the Laboratory of Glaciology and Geophysical Environment of the University of Grenoble, offering $40 \%$ relative efficiency and a $4 \pi$ counting geometry. Standards for ${ }^{210} \mathrm{~Pb}$ and ${ }^{137} \mathrm{Cs}$ are those of the CEA and Amersham laboratories (2\% uncertainty at $95 \%$ confidence level). Background level was $1.069 \pm$ 0.104 counts $\mathrm{h}^{-1} \mathrm{keV}^{-1}$ (cph keV ${ }^{-1}$ ) for ${ }^{210} \mathrm{~Pb}$, and $1.204 \pm 0.028 \mathrm{cph} \mathrm{keV}{ }^{-1}$ for ${ }^{214} \mathrm{~Pb}$ and ${ }^{137} \mathrm{Cs}$. Accuracies are $\sim 10 \%$ for ${ }^{210} \mathrm{~Pb}$ and $20 \%$ for ${ }^{137} \mathrm{Cs}$.

Sediment grain-size measurements and mineralogical identifications

Grain size in core 09P2 was measured by laser diffractometry using a Malvern Masterizer 2000 Hydro particle size analyzer at the University of Lausanne, Switzerland. The sampling interval was kept close to the couplets rhythmicity by decreasing the sampling interval down core from $2.4 \mathrm{~cm}$ near the top to $0.8 \mathrm{~cm}$ near the bottom (average $1.5 \mathrm{~cm}$ ). Clays were dispersed using a commercial water softener (Calgon at $40 \mathrm{~g} \mathrm{l}^{-1}$ ) and organic debris was removed using $35 \mathrm{wt} \%$ hydrogen peroxide. Particle-size distributions were calculated using the software Gradistat (Blott and Pye 2001). An X-ray diffraction inventory of dominant mineral groups was obtained using a Thermo Xtra diffractometer at the University of Lausanne. For this latter purpose core 09P2 was sampled continuously, the thickness of the successive contiguous samples being determined by the amount of sediment necessary for each individual sample analysis $(3 \mathrm{~g})$. The resolution of the analysis thus increases down core, as sediment density increases, from $5 \mathrm{~cm}$ near the top to $0.8 \mathrm{~mm}$ near the base. Samples were prepared following the procedure of Kübler (1983, 1987) and Adatte et al. (1996), dried at a temperature of $60{ }^{\circ} \mathrm{C}$, and ground to a homogenous powder of particles finer than $80 \mu \mathrm{m}$. About $800 \mathrm{mg}$ of powder were pressed at 20 bars in a powder holder covered with blotting paper. Conversion of the XRD patterns to semi-quantitative analysis was done with external standards.

Scanning electron microscopy (SEM) was performed on selected samples of dark- and light-colored laminae using a Tescan Mira LMU at University of Lausanne. Samples were dried and lyophilized, and then coated with gold. An energy dispersive X-ray spectrometer (EDS) (Oxford Instruments) was used to identify particles that best fingerprint the lake sediment sources, such as euhedral quartz, magnetite, and 
Fig. 5 Correlation of sediment cores along a west-east transect with event layers $a-c$

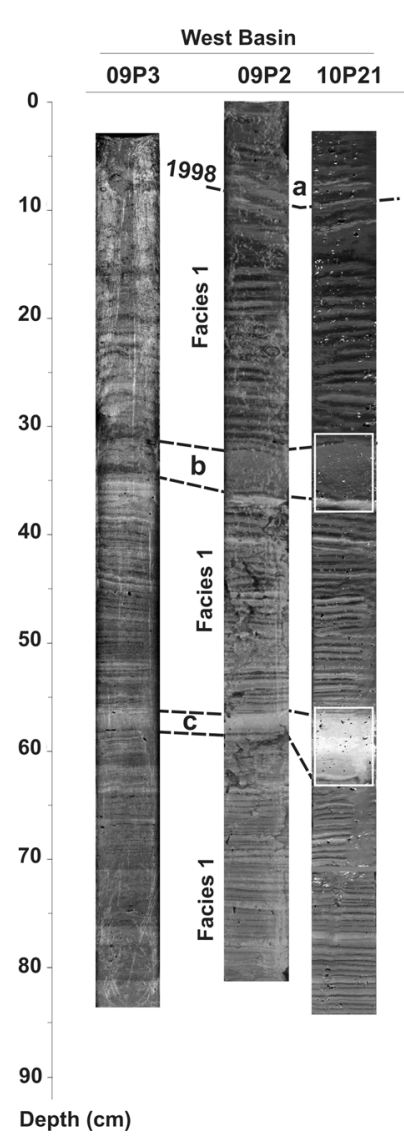

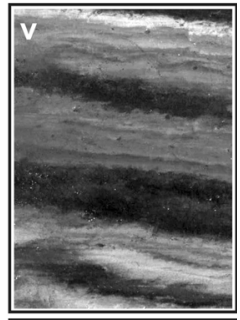

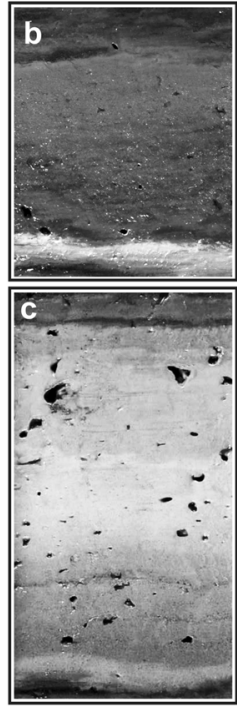

glass shards derived from the Los Chocoyos pumice, euhedral calcite precipitated on floating macrophytes, and framboidal pyrite produced by anaerobic bacterial activity on the lake floor.

\section{Results}

Core location and description

Three sediment cores (09P1, 09P2, 09P3) were collected in the West Basin (Fig. 1). Core 09P1 was retrieved from a depth of $9.6 \pm 1.1$ m near the delta of the Chijuljá River, core 09P2 from a depth of $22.2 \pm 1.0 \mathrm{~m}$ at the center of the basin, and core 09P3 from a depth of $19.0 \pm 1.0 \mathrm{~m}$ in a more distal part of the basin. The following year, duplicate cores (10P11, 10P21, 10P31) were obtained at similar locations, and new ones in the Peténcito Basin (10P61 and 10P62). The topmost sediment was difficult to recover because it is extremely loose, being rich in gas and organic debris; the top of sedimentary sequence is therefore lacking in most cores. The sediment is mostly composed of mm- to cm-thick dark-light laminae couplets (facies 1, Fig. 5). The couplets tend to thicken towards the river delta $(1-3 \mathrm{~cm})$ and to thin out in the Peténcito Basin $(0.5 \mathrm{~mm})$. The sedimentary succession in the West Basin is similar downcore throughout the basin, allowing for stratigraphic correlation of its most outstanding layers $(\mathrm{a}, \mathrm{b}, \mathrm{c})$. These layers are visibly thicker and coarser-grained than the laminated sediment, and fine upward like turbidites (Fig. 5). Two types of turbidites can be distinguished based on the color: a dark-colored type (such as layer 'b'), and a light-colored type (such as layer ' $c$ '). In the Peténcito Basin, the layering is interrupted down core at a depth of $13 \mathrm{~cm}$ by a 20 -cm-thick deposit, termed facies 2 . Facies 2 seems homogenous but actually retains faint lamination remnants. It rests itself on intensely deformed sediments (facies 3 ) that exhibit sub-horizontal hinges of meter-scale recumbent folds (Fig. 5). 


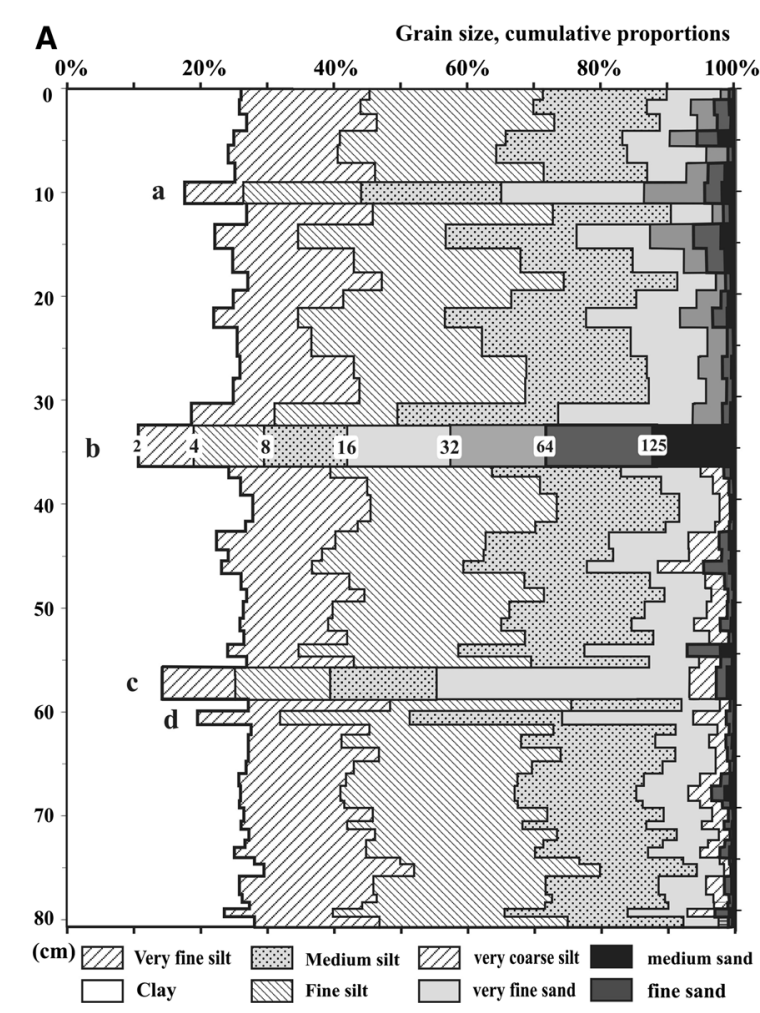

Fig. 6 Grain size and mineralogical variations along core 09P2. a Sediment grain size in cumulative vol\%. Numbers (2/4/ $8 / 16 / 32 / 64 / 125)$ refer to grain-size fractions in micrometers.

Grain-size distribution

The grain-size distribution of the non-organic fraction in facies 1 is fairly constant, as illustrated by core 09P2 (Fig. 6a). Clay (20-25 wt \%) and silt (75-80 wt \%) predominate over fine sand (5 wt $\%$ and less). We interpreted facies 1 as slow, dilute and continuous settling of fine suspended particles. A few thicker and/ or coarser-grained layers interrupt this fine layering, in particular a $4 \mathrm{~cm}$-thick, dark-colored layer 'at a depth of $35 \mathrm{~cm}$, and a 2-cm-thick, light-colored layer 'c' at a depth of $57 \mathrm{~cm}$, intermediate in grain-size between facies 1 and layer ' $b$ '. Thinner light-colored layers at depths of $10 \mathrm{~cm}$ (layer 'a') and $60 \mathrm{~cm}$ (layer 'd') stand out for their grain-size distribution similar to that of layer 'c'.

\section{Mineral composition}

X-ray diffraction analysis of core 09P2 (Fig. 6b) indicate predominance of phyllosilicates (58\%), carbonates $(23 \%)$, and quartz (6\%), over iron oxides

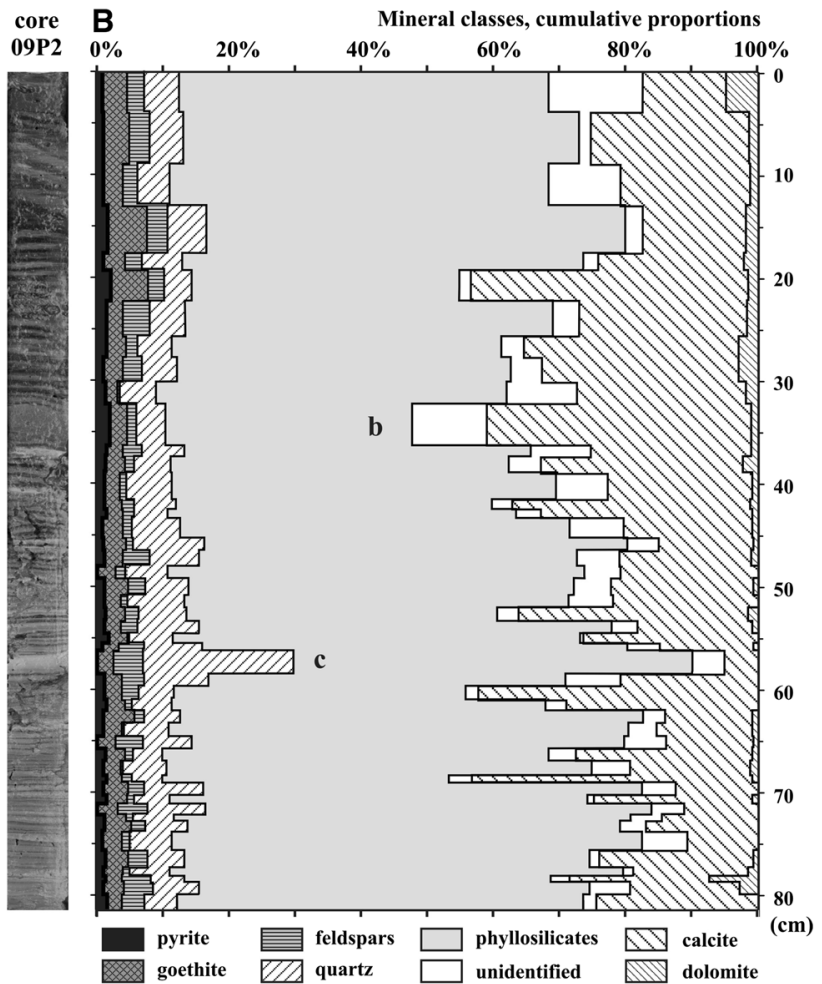

b Major minerals composition of the sediment in cumulative vol\% determined by X-ray diffraction

(3\%), feldspars (2\%) and pyrite (1\%). SEM inspection of the sediment shows that the phyllosilicate fraction is dominated by clays derived from the soils covering the carbonates. The X-ray spectrometer used during the SEM analysis reveals that the largest phyllosilicate grains are euhedral biotite flakes derived from the Los Chocoyos pumice (Fig. 7a) and muscovite flakes reworked from the Jurassic red beds. The darker laminae of facies 1 are rich in euhedral calcite (Fig. 7d) and plant remnants (Fig. 7b). This calcite is known to precipitate on floating macrophytes and on the aquatic plant assemblages fringing the lake (Alpizurez-Palma 1978). Some of the calcite may be of detrital origin and come from the poorly exposed Cretaceous and Permian carbonates of the lake catchment. Quartz comes from the Los Chocoyos pumice (euhedral crystals), and from the Jurassic red beds (polycrystalline grains). Iron oxides are mostly derived from the red soils over the carbonates, and to a lesser extent from the Jurassic red beds. The noncrystalline fraction comprises amorphous biogenic silica (diatoms, Fig. 7d) and volcanic glass (Los 

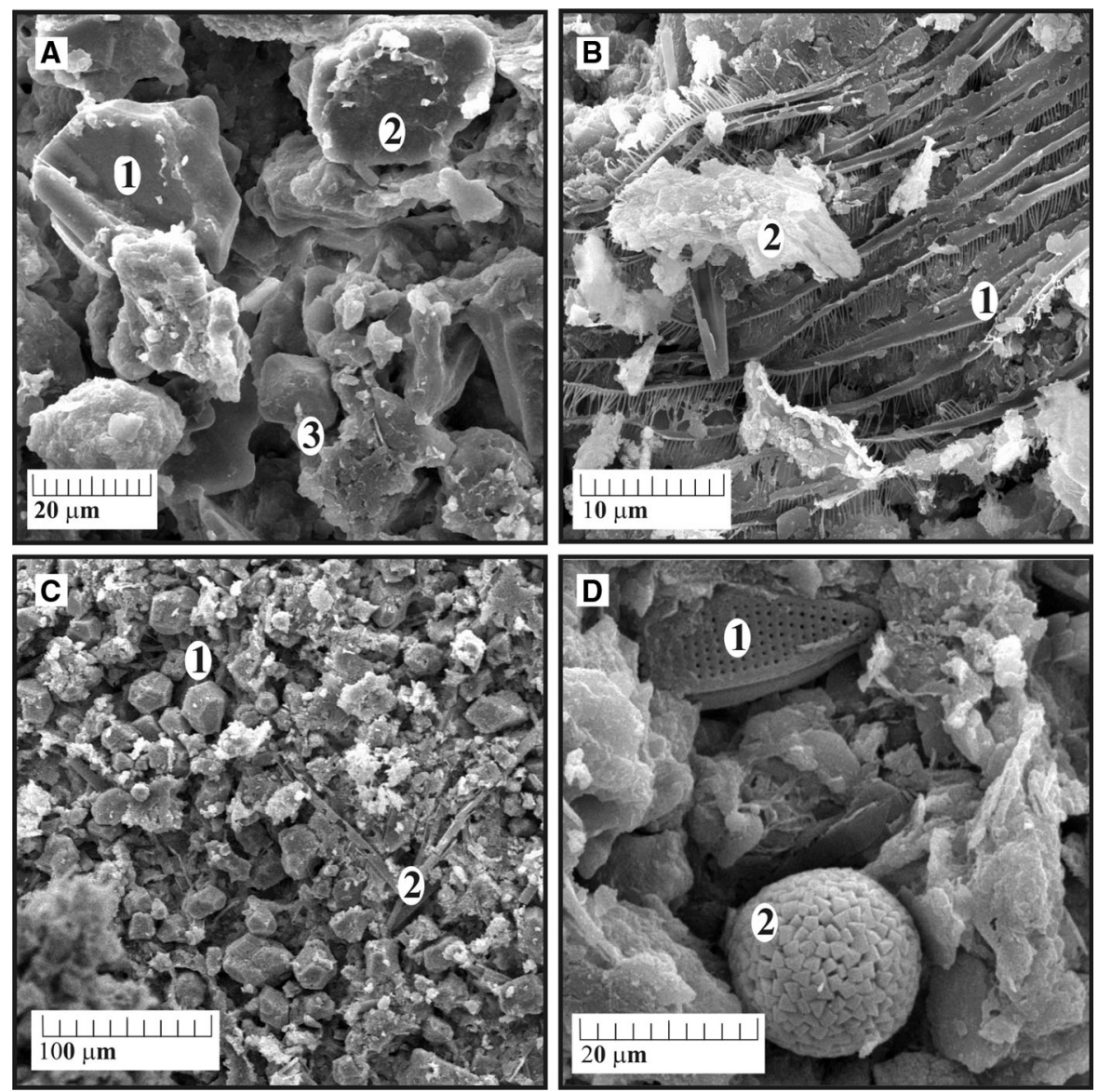

Fig. 7 SEM photographs of chosen sediment layers. a Pumicerich flood layer. 1 Volcanic glass, 2 biotite, 3 magnetite. Depth $30 \mathrm{~cm}, 1989$ AD. b Organic rich layer. 1 Floating macrophyte root debris [Eishhornia crassipes, (Mart.) Solms], 2 clay coating. Depth $39 \mathrm{~cm}, 1984$ AD. c Authigenic production

(epilimnium): 1 neoformed calcite, 2 plant debris. Depth $51 \mathrm{~cm}$, 1977 AD. d Authigenic production: 1 diatom (epilimnium), 2 pyrite frambroid (hypolimnium/lake floor). Depth $51 \mathrm{~cm}, 1977$ $\mathrm{AD}$

Chocoyos pumice, Fig. 7a). Pyrite is produced by microbial anaerobic decomposition of organic matter on the lake floor, where it forms framboid crystals (Fig. 7d).

The coarse-grained dark layer ' $b$ ' is enriched in carbonates and organic debris compared to the average sediment. Conversely, the light-colored layer ' $c$ ' is highly depleted in carbonates and enriched in quartz. The coarse resolution of the XRD analysis prevented analyzing the thin layers ' $a$ ' and ' $d$ '.

Sedimentation rate inferred from the ${ }^{210} \mathrm{~Pb}$ and ${ }^{137} \mathrm{Cs}$ inventories

Core 09P2 displays the longest record and was therefore selected for the ${ }^{210} \mathrm{~Pb}$ inventory. Yet its

${ }^{210} \mathrm{~Pb}_{\mathrm{exc}}$ inventory is still incomplete because the core is not long enough to reach the fully supported layers older than $1835 \mathrm{AD}$ (Fig. 8a). We therefore applied a Constant-Flux, Constant-Sedimentation model (CRCS, Goldberg 1963; Krishnaswami et al. 1971) from the surface down to the base of the core to derive an average sedimentation rate of $1.27 \pm 0.12 \mathrm{~cm}$ year ${ }^{-1}$. The activity of ${ }^{137} \mathrm{Cs}$ provides an independent time benchmark (Fig. 8b). ${ }^{137} \mathrm{Cs}$ is a product of atmospheric nuclear testing and accidental releases from nuclear power plants. The first fallouts of atmospheric nuclear tests occurred in the early 1950s. In the northern tropics atmospheric releases peaked in $1963 \pm 2$ and ended with the last atmospheric testing in the early 1980s. In core 09P2 the ${ }^{137} \mathrm{Cs}$ peak is encountered at a depth of $45.2 \pm 0.5 \mathrm{~cm}$. 


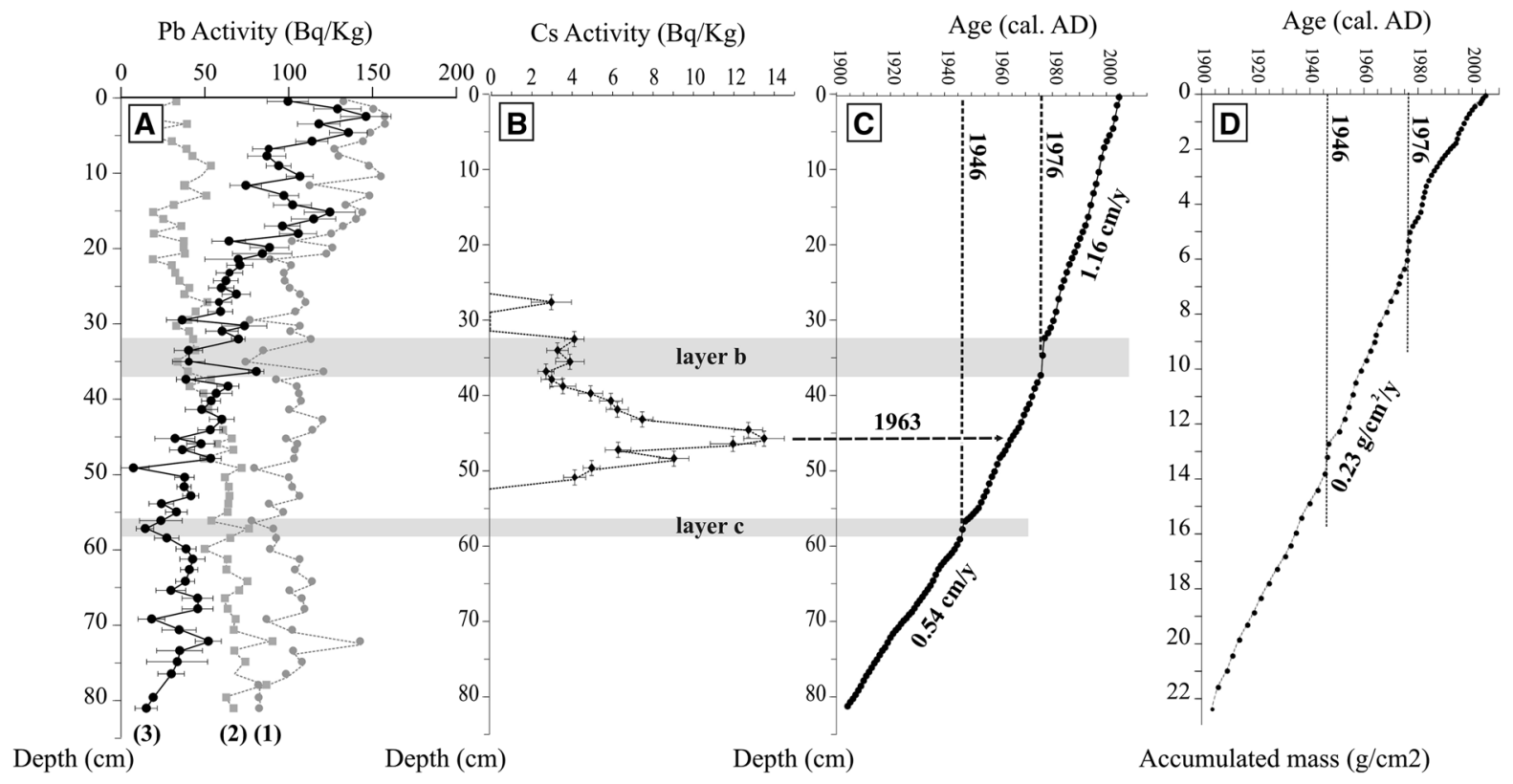

Fig. 8 Determination of sediment ages and sedimentation rates. a Total ${ }^{210} \mathrm{~Pb}(1)$, compensated ${ }^{210} \mathrm{~Pb}(2)$, and inferred excess ${ }^{210} \mathrm{~Pb}(3)$ activities versus depth in the Laguna Chichój core $09 \mathrm{P} 2 . \mathbf{b}^{137} \mathrm{Cs}$ activity versus depth. c Calendar age model

Assuming no loss of topmost sediment, it indicates a minimum sedimentation rate of $0.98 \pm 0.01 \mathrm{~cm}$ year $^{-1}$ after $1963 \pm 1 \mathrm{AD}$, consistent with the rate based on the ${ }^{210} \mathrm{~Pb}$ activity.

\section{Discussion}

Genesis of the lake

The circular depressions that the lake occupies are similar to the innumerous dolines of the surrounding cockpit karst. These dolines are produced by dissolution of Cretaceous and Permian limestone and dolomite. However, these dolines do not retain any similar permanent deep ( $>2 \mathrm{~m}$ ) water body. The proximity of an important body of gypsum suggests that the dolines in Lake Chichój are formed by dissolution over a more impervious body of evaporites more likely to host a perennial lake (Supplementary Material 2). The high dissolution rate of the gypsum in this tropical climate probably results in fast ground subsidence, and may help maintain a positive accommodation space in spite of high rate of sedimentation in lake, thus lengthening obtained by varve counting, tuned to the 1976 turbidite. d Mass accumulation with time calculated by combining the calendar age model with bulk density measurements

its lifetime. Subsidence could be continuous, or occur in increments during sudden events such as the hypothetical sixteenth century collapse thought to have destroyed the antique city of San CristóbalCaccój (Gage 1648; Viana et al. 1955).

Annual layering and twentieth century age model

The light and dark laminae in facies 1 are mostly made of clays settled out of dilute clayey to silty suspensions. A few larger particles settled with the clays, either because they stayed in suspension owing to their large surface-to-volume ratio (micas and pumice shards), or because they fell from the floating macrophyte rafts (euhedral calcite). The light-colored laminae thicken towards the Chiljuljá River delta, indicating that the river is the main source of detrital sediment. Near the river delta the lighter laminae exhibit stacked internal sub-laminations representing distinct pulses of sediment injection during the wet season (Fig. 5). Conversely, the dark laminae are depleted in clays and are rich in organic debris and biogenic calcite (Fig. 7), indicating limited terrigenous input during dark laminea deposition. We 
therefore interpret the white and dark layers are true varves recording the annual alternation of the wet season, from May to September, with the dry season, from November to April.

Varve counting indicates that core 09P2 represents 96 years, which is consistent with the non-extinction of ${ }^{210} \mathrm{~Pb}_{\mathrm{exc}}$ at the base of the core. Once pinned to the $1963 \pm 2 \mathrm{AD}{ }^{137} \mathrm{Cs}$ peak (Fig. 8c), the varve model correctly predicts first and last fallouts of ${ }^{137} \mathrm{Cs}$ in the early 1950s and early 1980s, respectively, and is consistent with the history of ${ }^{137} \mathrm{Cs}$ release in the Earth's atmosphere. Propagated upcore it yields an age of $2005 \pm 2 \mathrm{AD}$ for the top of core 09P2. Once excluded anomalous layers ' $b$ ' and 'c', the varve counting reveals an increase in apparent sedimentation rate from a steady $0.54 \mathrm{~cm}_{\text {year }}{ }^{-1}$ below layer ' $\mathrm{b}$ ', to $1.16 \mathrm{~cm}$ year $^{-1}$ afterwards (Fig. 5c). This apparent increase is an effect of sediment compaction; by mass, the accumulation of sediment remained constant at $0.23 \mathrm{~g} \mathrm{~cm}^{-1}$ (Fig. 5d). The sedimentation rate increases to $1.62 \mathrm{~cm} \mathrm{year}^{-1}\left(1.1 \mathrm{~g} \mathrm{~cm}^{-1}\right)$ near the river delta, but drops considerably down to $0.56 \mathrm{~cm}$ year $^{-1}$ further east beyond the shallow sill that separates the river delta from the Peténcito Basin.

Sensitivity of the sediment record to earthquakes

With its deep but clearly separated basins, the lake offers the opportunity to distinguish randomly produced slope failures from earthquake-triggered failures, because turbidites and slumps occurring at the same time in separate basins are almost certainly generated by earthquakes (Strasser et al. 2006; Goldfinger 2011). Significant lake level lowering could also trigger widely distributed failures, but in spite of a possible leakage through the lake floor (Supplementary Material 1), Lake Chichój maintains a positive water balance, relatively stable lake-level, and surface outflow throughout the year (Alpizurez-Palma 1978).

Dark layer ' $b$ ' is present in all cores in the West basin (Fig. 5). It is coarser-grained than the varved sediment of facies 1, and normally-graded (Fig. 5). It also contains more carbonate than the average sediment (Fig. 6). Carbonate-rich and is found all around the lake near the shoreline due to abundant biogenic calcite production and minimal terrigenous inputs (Alpizurez-Palma 1978). We therefore interpret layer ' $b$ ' as a turbidite generated by the failure of a nearshore slope. According to the age model this event would have occurred in $1976 \pm 2$ years. Layer 'b' is not observed at shallow depth in the core near the river delta. The high biogenic and low terrigenous content of layer ' $b$ ' precludes that it originated in the delta region and moved away. Its absence in the delta therefore rather indicates that the turbidity currents that formed layer ' $b$ ' were not energetic enough to flow upslope as far as over the river delta.

The Peténcito Basin is separated from the West Basin by a sill only 2-m-deep that keeps it isolated from the turbidity currents of the West Basin. The Peténcito hosts its own slope failures, evidenced by facies 2 and 3 in cores 10P62 and 10P61 (Fig. 5). The recumbent folds of facies 3 represent slide or slump deposits (Mulder and Cochonat 1996), and are draped by a homogenized layer of disaggregated sediment (facies 2). An incomplete sequence of 20 varves seals facies 2, providing a minimum age of $1989 \mathrm{AD}$ for the mass wasting event. This very dark varve sequence is similar to the most recent varves encountered in the other cores. Their high organic content reflects strong eutrophication of the lake since the 1960s (AlpizurezPalma 1978; Arce-Canahui 1992), indicating that the event cannot be older than the 1960s.

No other mass wasting events were detected in the sediment cores, and the identified events temporally match a well-known earthquake. Among all earthquakes susceptible to have shaken the lake area (Fig. 2b), the 1976 earthquake is by far the most powerful. It is also the only one that caused significant damage to the town of San Cristóbal. The modeled age of turbidite 'b' matches exactly the 1976 earthquake. The mass movement in the Peténcito Basin occurred between the 1960s and 1989. It could have occurred randomly, or could have been triggered by earthquakes in 1985, 1976 and 1971, but because the 1976 earthquake was felt so strongly in San Cristóbal, and because it generated a turbidite in the West Basin, we regard it as the trigger for the mass movement in the Peténcito Basin.

Subaerial landslides were also triggered by the 1976 earthquake all over the central highlands (Fig. 2b; Espinoza et al. 1976) in areas struck with MMIs of VII and higher (Fig. 2b; Harp et al. 1981). The earthquake was felt in San Cristóbal with a MMI of VI. It also triggered slope failures in Lake Chichój, $20 \mathrm{~km}$ beyond the mapped area of subaerial landsliding. The susceptibility of the lake sediments to mass wasting is thus similar to that of unconsolidated 
pumice, which collapsed under MMIs of VI in the volcanic highlands (Fig. 2b). This is consistent with other limnological studies that have shown that the minimal MSK intensity required to trigger slope failures in lakes is VI-VII (Monecke et al. 2004), and that an MSK of VI is required to generate soft sediment deformation structures (Hibsch et al. 1997).

This threshold holds for Lake Chichój over the twentieth century: no other earthquake reached an intensity of VI in San Cristóbal (Fig. 2b), and accordingly, no other seismite is observed over the period 1903-2005 AD. Our team witnessed a $M_{s} 5.2$ earthquake at 8:21 a.m. on Sunday June 14th 2009 just a few hours before retrieving cores 09-P1, P2 and P3. This earthquake, centered $15 \mathrm{~km}$ north of the lake, was felt in San Cristóbal with a MMI of V (small fissures in the parochial church; people fleeing the morning service). Soft bed deformations observed near the top of cores 09P2 and 09P3 could result from the 2009 or 2001 earthquakes or could be simple coring artifacts.

\section{Sensitivity to large runoff events}

Layer ' $c$ ' is a conspicuous graded layer, like turbidite 'b' (Fig. 5), though finer-grained (Fig. 6a). It is very light-colored, and enriched in detrital minerals (Fig. 6b) originating from the catchment of the lake. We interpret this layer as a flood layer deposited by hyperpycnal flows during an exceptional runoff event (Lauterbach et al. 2012; Gilli et al. 2013), which according to our age model would have occurred in the 1940s (1946 \pm 2 AD). The most complete list of tropical depression tracks available (NOAA 2012) reveals the passage of nine tropical storms centers within $100 \mathrm{~km}$ of Lake Chichój between 1910 and 2010 (Fig. 2a). The temporally closest and most powerful storms capable of producing flood layer ' $c$ ' are, in order of decreasing probability, the transoceanic hurricane H2 on October 4-5th 1945, a tropical storm on October 23th 1943, and a transatlantic hurricane on September 29-30th, 1949.

Layer ' $\mathrm{a}$ ', at a depth of $10 \mathrm{~cm}$ in core 09P2, and layer 'd', just below layer 'c', are other coarse, lightcolored layers similar to layer 'c' (Fig. 6a). Layer 'a' temporally matches Hurricane Mitch, which shed $240-580 \mathrm{~mm}$ of precipitations in 4 days over the catchment of Lake Chichój (unpublished meteorological data of the Instituto Nacional de Electrificación,
INDE, Guatemala). Hundreds of landslides were triggered in its area of most intense precipitation, which terminates $20 \mathrm{~km}$ to the SW of the lake (Bucknam et al. 2001). No landslide occurred in the lake catchment, and this probably explains why the flood layer is so thin. Conversely, the inhabitants of San Cristóbal have kept the memory of dramatic dwelling destructions by landslides or/and debrisflows in the southwestern part of the town "during a great flood in the 1940s". The great thickness of layer 'c' could result from the release the sediments produced by these slope failures into the lake. The hurricanes of the 1940s are not considered regionally as intense as Mitch; therefore, rather than a much more exceptional event, the $\sim 1946$ AD storm was possibly just a bit more intense than Mitch in San Cristóbal, just enough to reach the duration-intensity rainfall threshold necessary for the initiation of landsliding (Larsen and Simons 1993). This threshold effect makes the recording of flood layers highly skewed. In addition, the value of this threshold is not constant in manmodified catchments and may be lowered by human activity (such as deforestation or urbanization). The complex water routing in the lake catchment (Supplementary Material 1), and the time at which the flooding occurs during the cycle of water stratification/homogenization of the lake can also modulate the sediment concentration in the water entering the lake, affect the generation of hyperpycnal flows (Mulder et al. 2003), and sediment avalanching on the river delta (Wirth et al. 2011). These complexities call for caution in establishing a relationship between flood layer thickness and storm intensity.

\section{Conclusion}

The bathymetric survey undertaken in Lake Chichój reveals that the lake occupies aligned coalescent dolines. The dolines probably result from the dissolution of a buried body of gypsum. Rapid subsidence may help keeping pace with sediment filling, allowing for the lake to persist over time. This peculiar geologic setting is unique in central Guatemala, and probably explains why Lake Chichój is the only permanent deep lake of the central highlands.

The ${ }^{210} \mathrm{~Pb}$ and ${ }^{137} \mathrm{Cs}$ inventories in a short gravity core evidence high mass accumulation rates during the twentieth century, reaching $0.23 \mathrm{~g} \mathrm{~cm}^{-1}$ in the West 
Basin, and $1.1 \mathrm{~g} \mathrm{~cm}^{-1}$ near the main river delta. Biogenic lacustrine production and detrital influxes are equally high, and dominate in alternation between the dry and wet seasons, producing varve couplets 0.5 to $1.2-\mathrm{cm}$-thick in basinal areas, and up to $3 \mathrm{~cm}$-thick near the main river delta.

The varve series is interrupted by turbiditic layers with distinct geochemical characteristics, allowing discrimination of different source areas and triggering processes. In the West Basin, varved sedimentation is interrupted by a turbidite layer, richer in carbonates and organic debris than the varved sediment produced following the failure of a slope near the shore. It is coeval to folded and homogenized sediments also generated by mass movements in the Peténcito Basin. The composition of the dark, failure-induced turbidite contrasts with that of light-colored turbidites, rich in catchment-derived detrital constituents interpreted as flood layers.

Lake Chichój lies within an array of large active tectonic faults forming the plate boundary between the North American and Caribbean Plates. The lake is located only $2 \mathrm{~km}$ from the Polochic fault, a major fault known to have produced large $\left(\mathrm{M}_{\mathrm{s}}\right.$ 7.0-7.6) earthquakes in 1816 and 1785 (White 1984). In the twentieth century, however the Polochic fault has only produced minor earthquakes that did not affect the lake. The turbidites and slumps discovered in the lake coincide with a large event $\left(M_{w} 7.5\right)$ that occurred in 1976 along the Motagua fault, $45 \mathrm{~km}$ south of the lake. This event was felt at the lake with a local MMI of VI. Like in other lakes worldwide, a MMI of VI is thus the threshold necessary to produce mass movements. Dramatic seismites must have been triggered by the 1815 and 1785 earthquakes produced by the Polochic fault.

Direct rainfall measurements in the lake catchment started only in 1979. It is assumed that before that date, the most intense rainfall events of the twentieth century resulted from tropical cyclonic depressions and that their record can be approximated by the tracks of the tropical storms that have struck Guatemala. Hurricane Mitch, in 1998, was the only large hurricane for which direct rainfall measurements are available, produced abundant rainfall in the lake catchment but only left a modest flood layer in the sediment record. The only prominent flood layer in the sediment record correlates to one of three hurricanes in the 1940s, which is known to have generated destructive landslides and/or debris flows in the lake catchment. It is therefore hypothesized that conspicuous flood layers are only formed when the rainfall-duration intensity threshold of landsliding is reached in the lake catchment, providing abundant sediments, high sediment concentration in the streams, and hyperpycnal flows in the lake.

The recovery of longer cores spanning a much longer time period is necessary to assess the recurrence interval of large magnitude earthquakes and hurricanes in Central Guatemala. However, due to the limited areal extent of the destructions that they generate, the study of several lakes in various locations will be necessary to accurately evaluate the hazard such phenomenon pose to the country.

Acknowledgments This work was supported by Swiss National Science Foundation Grants 200021-112175/1 and 200020-120117/1. We thank Alois Zwyssig at the Swiss Federal Institute of Aquatic Science and Technology (Eawag), and Céline Pignol at the Edytem, University of Savoie, France, for their technical support during core opening. We thank two anonymous reviewers for their thorough review that significantly improved the manuscript.

\section{References}

Adatte T, Stinnesbeck W, Keller G (1996) Lithostratigraphic and mineralogic correlations of near $\mathrm{K} / \mathrm{T}$ boundary clastic sediments in northeastern Mexico: implication for origin and nature of deposition. Geol Soc Am Spec Publ 307:211-226

Alpizurez-Palma JR (1978) Estudio ecológico de la Laguna Chichój. Engineering Master's thesis, University of San Carlos de Guatemala

Alvarez-Rangel N (1995) Análisis multielemental por reflexión total de rayos X, en tejido muscular de lobina Micropterus salmoides (lacepade) y guapote Cichlasoma maneguense (Gunter), en la laguna de Chichój, San Cristóbal Verapaz. Biology engineering Master's thesis, University San Carlos de Guatemala

Anselmetti FS, Ariztegui D, Brenner M, Hodell D, Rosenmeier MF (2007) Quantification of soil erosion rates related to ancient Maya deforestation. Geology 35:915-918

Arce-Canahui A (1992) Caracterización biofísica y socioeconómica de la cuenca de la Laguna Chichój. Univ San Carlos Guatemala, Dirección General de Investigación

Arnaud F, Lignier V, Revel M, Desmet M, Beck C, Pourchet M, Charlet F, Trentesaux A, Tribovillard N (2002) Flood and earthquake disturbance of ${ }^{210} \mathrm{~Pb}$ geochronology (Lake Anterne, NW Alps). Terra Nova 14:225-232

Authemayou C, Brocard G, Teyssier C, Suski B, Cosenza-Muralles B, Morán-Ical S, González-Véliz CW, AguilarHengstenberg M-A, Holliger K (2012) Quaternary seismo- 
tectonic activity of the Polochic Fault, Guatemala. J Geophys Res 117:B07403. doi:10.1029/2012JB009444

Bettini A (2011) Anthropisation du lac Chichój, San Cristóbal Verapaz, Guatémala. Master's thesis, Université de Lausanne, Switzerland

Binford MW, Brenner M, Leyden BW, Whitmore TJ, HigueraDiaz A, Deevey ES (1987) Ecosystems, paleoecology, and human disturbance in subtropical and tropical America. Quat Sci Rev 6:115-128

Blott SJ, Pye K (2001) Gradistat: a grain size distribution and statistics package for the analysis of unconsolidated sediments. Earth Surf Proc Land 26:1237-1248

Brezonik PL, Fox JL (1974) The limnology of selected Guatemalan Lakes. Hydrobiologia 45:467-487

Bucknam RC, Coe JA, Mota-Chavarría M, Godt JW, Tarr AC, Bradley L-A, Rafferty S, Hancock D, Dart RL, Johnson ML (2001) Landslides triggered by Hurricane Mitch in Guatemala-inventory and discussion. US Geol Surv Open-File Report 01-443

Drexler WJ, Rose WL, Sparks RSJ, Ledbetter MT (1980) The Los Chocoyos Ash, Guatemala: a major stratigraphic marker in Middle America and in three ocean basins. Quat Res 13:327-345

Espinoza AF, Husid R, Quesada A (1976) Intensity distribution and source parameters from field observations. In: Espinoza AF (ed) The Guatemalan Earthquake of February 4, 1976, a preliminary report. US Geol Surv Prof Paper 1002, 52-62

Friedel MJ (2008) Tegularized joint inverse estimation of extreme rainfall amounts in ungauged coastal basins of El Salvador. Nat Hazards 46:15-34

Gage T (1648) New survey of the West Indies, or the EnglishAmerican his travel by sea and land. A. Clark, London, 1677

Gilli A, Anselmetti FS, Glur L, Wirth SB (2013) Lake sediments as archives of recurrence rates and intensities of past flood events. In: Schneuwly-Bollschweiler M, Stoffel M, Rudolf-Miklau F (eds) Dating torrential processes on fans and cones-methods and their application for hazard and risk assessment. Adv Glob Change Res 47:225-242

Goldberg ED (1963) Geochronology with ${ }^{210} \mathrm{~Pb}$. Radioactive dating, 7 Int Atomic Energy Agency: 121-131

Goldfinger C (2011) Submarine paleoseismology based on turbidite records. Ann Rev Marine Sci 3:35-66

Guerra-Noriega A (2010) Climate-related disaster risk in mountain areas: the Guatemalan Highlands at the start of the 21 st century. PhD, University of Oxford, Oxford, UK

Harp EL, Wilson RC, Wieczorek GF (1981) Landslides from the February 4, 1976, Guatemala earthquake. US Geol Surv Prof Paper 1024-A

Hernandez-Suarez FJ, El-Daoushy F (2002) Semi-empirical method for the self-absorption correction of photons with energies as low as $10 \mathrm{keV}$ in environmental samples. Nucl Instrum Methods Phys 484:625-641

Hibsch C, Alvarado A, Yepes H, Perez VH, Sébrier M (1997) Holocene liquefaction and soft-sediment deformation in Quito (Ecuador): a paleoseismic history recorded in lacustrine sediments. J Geodyn 24:259-280

INDE (1974) Pueblo Viejo Project Feasibility Study. Instituto Nacional de Electrificación, Guatemala
INSIVUMEH-Instituto Nacional de Sismologia, Vulcanologia, Meteorologia y Hidrologia. http://www.insivumeh. gob.gt

Krishnaswami D, Lal JM, Martin M, Meybeck M (1971) Geochronology of lake sediments. Earth Planet Sci Lett 11:407-414

Kübler B (1983) Dosage quantitatif des minéraux majeurs des roches sédimentaires par diffraction X. Cahier de l'Institut de Géologie de Neuchâtel, Switzerland, ADX 1.1-1.2

Kübler B (1987) Cristallinité de l'illite, méthodes normalisées de préparations, méthodes normalisées de mesures. Cahier de l'Institut de Géologie de Neuchâtel, Switzerland, ADX. 1.3

Larsen MC, Simon A (1993) A rainfall intensity-duration threshold for landslides in a humid-tropical environment, Puerto Rico. Geografiska Annnaler 75A:13-23

Lauterbach S, Chapron E, Brauer A, Hüls MM, Gilli A, Araud F, Piccin A, Nomade J, Desmet M, von Grafensteiun U (2012) DecLakes participants (2012) a sedimentary record of Holocene surface runoff events and earthquake activity from Lake Iseo (Southern Alps, Italy). The Holocene 22:749-760

Lopez F (1999) Evaluación Hidrológia de las Crecidas Provocadas por el Paso del Huracán Mitch en Guatemala. PHI/ UNESCO, Montevideo

Lyon-Caen H, Barrier E, Lasserre C, Franco H, Arzú I, Chiquín L, Chiquín M, Dusquesnoy T, Flores O, Galicia O, Luna J, Molina E, Porras O, Requena J, Robles V, Romero J, Wolf R (2006) Kinematics of the North American-CaribbeanCocos plates in Central America from new GPS measurements across the Polochic-Motagua fault system. Geophys Res Let 33:L19309. doi:10.1029/2006GL027694

Malaizé B, Bertran P, Carbonel P, Bonnissent D, Charlier K, Galop D, Imbert D, Serrand N, Stouvenot C, Pujol C (2011) Hurricanes and climate in the Caribbean during the past 3700 years BP. Holocene 21:911-924

Mijangos N (2000) Caracterización y diagnóstico de la calidad de agua de las fuentes contaminantes de la cuenca y de la Laguna Chichój, San Cristóbal, Verapaz y Alta Verapaz. Fondo Guatemalteco del Medio Ambiente, Guatemala

Monecke K, Anselmetti FS, Becker A, Sturm M, Giardini D (2004) The record of historic earthquakes in lake sediments of Central Switzerland. Tectonophysics 394:21-40

Mouriño C, Basterrechea M, Molina S, De Zepeda M, De Juárez Y, Aguilar E, Oliva B, Castellanos P, Palacios R, Palma J (1994) Calidad de agua y nivel trófico de la laguna Chichój, Alta Verapaz, Guatemala. Guatemala, Dirección de Energía Nuclear de Guatemala, Ciencia y Tecnología Nuclear $1: 32-42$

Mulder T, Cochonat P (1996) Classification of offshore mass movements. J Sediment Res 66(1):43-57

Mulder T, Syvitski JPM, Migeon S, Faugères J-C, Savoye B (2003) Marine hyperpycnal flows: initiation, behavior and related deposits. A review. Mar Petrol Geol 20:861-882

Musk LF (1988) Weather systems. Cambridge University Press, Cambridge

Newhall CG, Paull KC, Bradbury JP, Higuera-Gundy A, Poppe LJ, Self S, Bonar Sharpless N, Ziagos J (1987) Recent geologic history of Lake Atitlán, a caldera lake in western Guatemala. J Volcanol Geothermal Res 33:81-107 
NOAA (National Oceanic and Atmospheric Administration), Historical Hurricane Tracks. http://maps.csc.noaa.gov/ hurricanes/\#

Noller JS (2000) Lead-210 geochronology. In: Noller JS (ed) Quaternary geochronology methods and applications. American Geophysical Union, Washington, AGU Reference Shelf 4:115-120

Plafker G (1976) Tectonic aspects of the Guatemala earthquake of 4th February 1976. Science 93:1201-1208

Poppe LJ, Paull CK, Newhall CG, Bradburz JP, Ziagos J (1985) A geophysical and geological study of Laguna de Ayarza, a Guatemalan caldera lake. J Volcanol Geothermal Res 25:125-144

Rose WI, Newhall CG, Bornhorst TJ, Self S (1986) Quaternary silicic pyroclastic deposits of Atitlán caldera, Guatemala. In Williams SN Carr MJ (eds) Stoiber RE 75th birthsday volume. J Volcanol Geothermal Res 33:57-80

Schnellmann M, Anselmetti FS, Giardini D, McKenzie JA, Ward S (2002) Prehistoric earthquake history revealed by lacustrine slump deposits. Geology 3:1131-1134

Strasser M, Anselmetti FS, Fäh D, Giardini D, Schnellmann M (2006) Magnitudes and source areas of large prehistoric northern Alpine earthquakes revealed by slope failures in lakes. Geology 34:1005-1008

Suski B, Brocard G, Authemayou C, Consenza-Muralles B, Teyssier C, Holliger K (2010) Localization and characterization of an active fault in an urbanized area in central Guatemala by the means of geoelectrical imaging. Tectonophysics 480:88-98

Swierczynski T, Brauer A, Lauterbach S, Martín-Puertas C, Dulski P, von Grafenstein U, Rohr C (2012) A 1600 yr seasonally resolved record of decadal-scale flood variability from the Austrian Pre-Alps. Geology 40:1047-1050

Terga R (1979) Caccoh, Donde Brota el Mar Pequeño. Instituto Indígena Nacional, Guatemala: Guatemala Indígena 14

Viana F, Gallego L, Cadena G (1955) Relación de la provincia de la Verapaz, hecha por los religiosos de Santo Domingo de Cobán, Guatemala (1574). An Soc Geog Hist Guatemala 28:18-31

White RA (1984) Catalog of historic seismicity in the vicinity of the Chixóy-Polochic and Motagua faults, Guatemala. US Geol Surv open-file report, 84-88

White RA, Harlow DH (1993) Destructive upper-crustal earthquakes of Central America since 1900. Bull Seismol Soc Am 83:115-1142

White RA, Ligorria JP, Cifuentes IL (2004) Seismic history of the Middle America subduction zone along El Salvador, Guatemala, and Chiapas, Mexico: 1526-2000. In: Rose WI, Bommer JJ, López DL, Carr MJ, Major JJ (eds), Natural hazards in El Salvador. Geol Soc Am Spec Paper 375:379-396

Wilhelm B, Arnaud F, Enters D, Allignol F, Legaz A, Magand O, Revillon S, Giguet-Covex C (2012) Does global warming favour the occurrence of extreme floods in European Alps? First evidences from a NW Alps progracial lake sediment record. Climate Change. doi:10.1007/ s10584-011-0376-2

Wirth SF, Girardclos S, Rellstab C, Anselmetti F (2011) The sedimentary response to a pioneer geo-engineering project: tracking the Kander River deviation in the sediments of Lake Thun (Switzerland). Sedimentology 58:1737-1761 